\title{
Preparation and Antimicrobial Activity Analysis of Organic Soap Bar Containing Gnetum Gnemon Peel Extract
}

\author{
Sri Handayani ${ }^{*}$, Indyah Sulistyo Arty ${ }^{a}$, Cornelia Budimarwantia, Karim Theresih ${ }^{a}$, Evy Yulianti ${ }^{b}$, Melati \\ Khairuddean ${ }^{c}$
}

\author{
${ }^{a}$ Chemistry Education Department, Faculty of Mathematics and Natural Sciences, \\ Universitas Negeri Yogyakarta, Indonesia \\ 'Biology Education Department, Faculty of Mathematics and Natural Sciences, \\ Universitas Negeri Yogyakarta, Indonesia \\ 'School of Chemical Sciences, Universiti Sains Malaysia, 11800 Penang, Malaysia
}

*Corresponding author email: handayani@uny.ac.id

Received July 06, 2021; Accepted August 26, 2021 ; Available online November 15, 2021

\begin{abstract}
Melinjo (Gnetum gnemon L.) peel has been known to contain antioxidant, antibacterial, and antifungal substances, yet it has not been widely used as cosmetic ingredients or drugs. This research focuses on the production of organic soap bars made of melinjo peel extract, quality testing, and analysis of the soap antimicrobial function against selected microbes. The soap bars were processed through the saponification reaction between the mixture of palm oil and coconut oil with sodium hydroxide through cold and hot processes. Distilled water and ethanol were used as solvents for melinjo peel extraction. The quality test was done by determining insoluble fractions in ethanol, free alkali, and unsaponified fatty matter. An antimicrobial activity test was conducted using the Kirby-Baver diffusion method. The result shows that the quality test fits with INS 2016 for all the criteria except for unsaponified fatty acid in the cold process soap bar. Inhibition zone of organic soap bar sequentially decreases against the growth of Tricophytone mentagrophytes, Staphylococcus aureus, and Staphylococcus epidermidis. Therefore, the organic soap bar with melinjo peel extract is feasible to be used as an antimicrobial soap.
\end{abstract}

Keywords: antimicrobial, cold process, hot process, melinjo peel extract, soap bar

\section{INTRODUCTION}

In the last two years, Indonesia and almost all countries in the world are experiencing an outbreak of the COVID-19 (Setiati \& Azwar, 2020). Generally, the spread of the virus is influenced by population density (Wong \& Li, 2020). Some researchers suggest handwashing with soap to prevent virus transmission (Amsal, 2020), (Wada \& Oloruntoba, 2021). However, frequent hand washing may lead to skin problems (Beiu, Mihai, Popa, Cima, \& Popescu, 2020). Therefore, it is compulsory to use the proper soap for frequent use.

Soap is a product of the saponification process between alkali $(\mathrm{NaOH}$ or $\mathrm{KOH})$ and triglyceride (McMurry, 2016). Triglyceride that has been widely used in organic soap preparation are palm oil, kernel oil, sesame oil (Semilin, 2014), and used cooking oil (Asmira, 2015). Organic soap is offered with additional functions as a skin deodorant softener and moisturizer. This type of soap also functions as a medical agent for reducing bacteria (Perencevich, Wong, \& Harris, 2001). To make a medical or cosmetic soap, additional materials are required, such as triclosan which is often added as an antimicrobial agent. However, triclosan has shown resistance to certain microbes (Giuliano \& Rybak, 2015). This substance is then replaced by an antimicrobial agent with biotic resources, such as Syzygium aromaticum essential oil that is believed to have no negative effects on the body (Handayani, Kristianingrum, Rakhmawati, \& Khairuddean, 2020). Natural soap additive in the form of dry powder is added directly as an exfoliant. Essential oil, a natural product extracted from methanol or ethanol, can also be used as an additive (Handayani, Kristianingrum, \& Rakhmawati, 2018).

One of Indonesia's native biotic resources that are easily grown in every region is melinio (Gnetum gnemon L.). Its leaf, fruit, and fruit peel have been used widely as foodstuff. Melinjo contains stilbene (Kato, Tokunaga, \& Sakan, 2009) with many kinds of different biological activities such as antioxidant activities in its leaves, tree barks, twigs, and seeds (Wazir, Ahmad, \& Muse, 2011), and antimicrobial activities in its seeds and peels. Melinjo has a substance that functions as skin whitening (Abhishek, Ruchi, Payal, \& Nilesh, 2019), and based on a toxicity 
test, melinjo seed is safe for consumption (Tatefuji, Yanagihara, Fukushima, \& Hashimoto, 2014). Nevertheless, melinjo has not been fully utilized either as a potential ingredient of beauty and medical products. This study tries to investigate melinjo potentials as a beneficial local product in the form of an organic antibacterial and antifungal soap that meets the qualification of Indonesian National Standard (INS). Moreover, the effect of the hot and cold processes in soap making also one of the highlights of this study.

\section{EXPERIMENTAL SECTION \\ Materials.}

Coconut oil, palm oil, and melinjo peels were purchased from a market located in Yogyakarta. Several chemicals such as $\mathrm{NaOH}$, petroleum ether, ethanol 95\%, alcoholic $\mathrm{KOH}$, sulphuric acid, $\mathrm{HCl}$, methyl orange, phenolphthalein, and acetone were purchased from Merck. Several microbes used in this research were Staphylococcus aureus, Staphylococcus epidermidis, and Tricophyton mentagrophyte. Meanwhile, the reagents for the antimicrobial test, for example, Nutrien Broth (NB, Oxoid), Nutrien Agar (NA, Oxoid), Potato Dextrose Agar (PDA, Oxoid), potato, glucose, brown paper were obtained from the Microbiology Laboratory at Faculty of Mathematics and Natural Sciences, Universitas Negeri Yogyakarta, Indonesia.

Tools.

Laboratory glassware, petri dish (Pyrex), drigalsky, laminar airflow (LAF), autoclave (Omron), incubator (Eyela SLI-600 N), centrifuge (H-103 N Kokusan), vortex (Sibata), and analytic scale (AND HR-250 A) were used in this study. Gas Chromatography Mass Spectroscopy (GCMS) was recorded on the GC17AMSQP 5000 Shimadzu. Statistical analysis was conducted using SPSS 21.

\section{Soap Production Through Hot and Cold Processes}

Melinjo peels were extracted using two solvents, namely water, and ethanol. As many as $7.7 \mathrm{~g}$ melinjo peels were heated in $100 \mathrm{~mL}$ of water for 10 minutes at $100^{\circ} \mathrm{C}$. Melinjo peels extracted using water was separated using filter paper and cooled to room temperature. Then, it was used to dissolve sodium hydroxide in soap making. Ethanol extract was prepared by macerating $7.7 \mathrm{~g}$ of melinjo peel with $100 \mathrm{~mL}$ of $95 \%$ ethanol at room temperature for 2 days. The crude extract was then filtered and evaporated for further use after the esterification reaction was completed (trace phase). Melinjo peel was used as an additive ( $3 \%$ of the total mass of vegetable oil). Organic soap was made by saponification reaction of approximately $35 \mathrm{~g}$ of $37 \%$ $(\mathrm{w} / \mathrm{v})$ sodium hydroxide and $250 \mathrm{~g}$ of vegetable oils ( $80 \%$ palm oil, $20 \%$ coconut oil as calculated by soapcalc.net). The mixture was stirred until the trace phase at room temperature (cold process), while the hot process was done at $70-80^{\circ} \mathrm{C}$ for two hours. Next, the mixture was poured into a mold and was left for 24 hours. The unmolding took place in 4 weeks for the cold process and 2 days for the hot process. The organic soap with melinjo peel additive went through the cold process using distilled water (A), the hot process using distilled water $(B)$, the cold process using ethanol (C), and the hot process using ethanol (D). The quality tests for the soap bars were focused on analyzing the free alkali content, insoluble ingredients in ethanol, and unsaponified fatty acid. The soap bar quality routine test was performed based on the Indonesian National Standard (INS) (BSN, 2016).

\section{Antimicrobial Test for The Organic Soap}

The bacteria strain was grown on nutrient agar, whereas the fungal strain was grown on potato dextrose agar at $37^{\circ} \mathrm{C}$. Antibacterial activity was determined by measuring the diameter of the inhibition zone. The relative antibacterial potential was measured by comparing the inhibition zone in the growth dish. The color resultant of the clear zone was measured in millimeters. The determination process of the inhibition zone using Kirby Baver disc method is explained in the following. One dose of S. epidermidis and $S$. aureus colony in an agar slant medium was taken and each was inoculated into $25 \mathrm{~mL}$ of an NB medium which was then incubated at $37^{\circ} \mathrm{C}$. Next, one dose of T. Mentagrophyte colony was taken and was inoculated into $25 \mathrm{~mL}$ of a potato dextrose broth medium and then incubated at $37^{\circ} \mathrm{C}$ for 24 hours until it looked cloudy. About $100 \mu \mathrm{L}$ of microbe suspension that has grown (cloudy in color) was taken using a micropipette and was inoculated onto a petri dish containing an agar medium and sterile drigalsky. The suspension was left for 3-5 minutes to be absorbed evenly before the absorbance was recorded in 200 ppm chloramphenicol for antibacterial, nystatin for antifungal as the positive control $\left(\mathrm{K}^{+}\right)$, and aquadest as negative control ( $\left.\mathrm{K}^{-}\right)$in the soap samples with 5,10 , $15,20,25,50,75$, and $100 \mathrm{mg} / \mathrm{mL}$ concentrations. Then, the blank disk with $100 \mu \mathrm{L}$ test sample was placed on the agar medium in the petri dish. These microbes on the discs were then incubated at $37^{\circ} \mathrm{C}$ for 24-96 hours. At last, the diameter of the inhibition zone around the paper disk was measured using calipers to determine the antibacterial activity.

\section{RESULTS AND DISCUSSION}

The main ingredients of the soap are vegetable oil triglyceride and sodium hydroxide. Other ingredients are additives such as fragrance, colorant, or substances that provide clinical effects. Bath additives are added to treat dry skin (Flavell, 2016) before the addition of organic soap additives, such as sunscreen, lightening, hair remover, and preservative. Medical practitioners and cosmetic manufacturers usually use safe herbs to substitute the harmful chemical or synthetic ingredients as an additive (Sharma, Agarwa, \& Kumar, 2003). In this research, melinjo peel extract is used as an additive for organic soap 
because of its various benefits. The soap bars made with melinjo peel additive are shown in Figure 1.

\section{Soap Quality Test}

The methods used to make the soap bars was the cold and hot processes. The cold process was carried out through the saponification reaction at room temperature, while the hot process went through the same reaction at the temperature of $70-80^{\circ} \mathrm{C}$ (Faiola, 2013). The shorter curing time is the advantage of hot processes because the soap produced can be used immediately after it hardens (Burleson, Butcher, Goodwin, Sharp, \& Ruder, 2017) whereas when produced in the cold processes, the soap needs a longer time, about 6-8 weeks. However, in the hot processes, it is difficult to modify the color and texture of the soap. The quality tests carried out in this research focus on the analysis of alkali content, insoluble ingredients in ethanol, and unsaponified fatty acid. The results of the soap quality test are summarized in Table 1 below.

The reaction between fatty acid and alkali produces good soaps. However, free alkali is a base that naturally does not react to form soap as it was found that excessive concentration of $\mathrm{NaOH}$ used during the saponification process may cause dry and irritated skin because the alkali is strong. According to INS 2016, the remaining free alkali must not be more than $2.5 \%$. In Table 1, the free alkali residue shows the value that meets the INS standard suggesting that the composition of oil and base used in the soap-making process is appropriate. Insoluble ingredients in ethanol which contains alkaline salts such as silicate, phosphate, and carbonate should not be more than
$5 \%$. The insoluble content in ethanol has also met the INS standard. Unsaponified fatty acid is the fatty acid that does not react to the saponification process, such as fat and oil, glyceride, and lanolin (BSN, 2016).

The determination of unsaponified fatty acid is influenced by the relative molecular mass of fatty acids in soap. In this study, the organic bath soap is made using two kinds of oils, namely coconut oil and palm oil. Coconut oil is mostly composed of lauric acid $\left(\mathrm{C}_{12}\right)$, while the main content of palm oil is oleic acid $\left(C_{18: 1}\right)$. The right composition of $\mathrm{C}_{12}$ and $\mathrm{C}_{18: 1}$ can produce $\mathrm{a}$ soap with high solubility and foam (Hall, Hill, Moaddel, \& Al, 2016).

The best fatty acid composition depends on the type and percentage of vegetable oil used. Available online applications might be used to determine it. Analysis using GC-MS is done for each vegetable oil to determine the average relative molecular mass $(M)$. Then, $M$ values (found based on the calculation resulted from previous studies conducted by Handayani et al., 2018) of these two vegetable oils are used to determine the unsaponified fatty acid. The unsaturated fatty acids composition as depicted in Table 2, is quite high because $80 \%$ of palm oil is used as the basic ingredient. Moreover, based on GCMS, the amount of fatty acid in palm oil is $50.9 \%$. The cold saponification process in Table 1 shows that the content of unsaponified fatty acids is higher than the requirement. This is due to the high composition of unsaturated fatty acids in the soap that is not fully saponified (Vidal et al., 2018). Therefore, in order to get better results and better soap quality, it is necessary to improve the triglyceride composition.
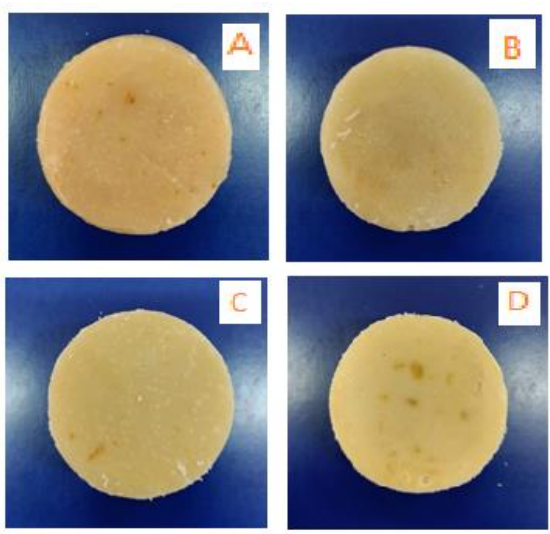

Figure 1. Organic soap with melinjo peel additive prepared through different processes: (A) cold process-distilled water, (B) hot process-distilled water, (C) cold process-ethanol, and (D) hot process-ethanol

Table 1. Soap quality test

\begin{tabular}{cccccc}
\hline Code & Solvent & Method & Free alkali (\%) & $\begin{array}{c}\text { Insoluble ingredients in } \\
\text { ethanol (\%) }\end{array}$ & $\begin{array}{c}\text { Unsaponified } \\
\text { fatty acid (\%) }\end{array}$ \\
\hline INS 2016 & & & Max. 2.5 & Max. 5.0 & Max. 0.5 \\
\hline A & water & cold process & 1.09 & 0.59 & 0.82 \\
B & water & hot process & 0.94 & 0.42 & 0.14 \\
C & ethanol & cold process & 0.71 & 0.41 & 0.63 \\
D & ethanol & hot process & 0.51 & 0.78 & 0.19 \\
\hline
\end{tabular}


Table 2. Molecular mass of fatty acids composition

\begin{tabular}{c|c|c}
\hline \multirow{2}{*}{ Fatty acids } & \multicolumn{2}{|c}{ Molecular mass x content from GCMS } \\
\cline { 2 - 3 } & Coconut oil (20\%) & Palm oil (80\%) \\
\hline Saturated fatty acid & 37.66 & 137.03 \\
$\mathrm{C}_{8}$ & 10.42 & - \\
$\mathrm{C}_{10}$ & 106.68 & - \\
$\mathrm{C}_{12}$ & 41.22 & - \\
$\mathrm{C}_{14}$ & & 18.93 \\
\hline Unsaturated fatty acid & - & 123.32 \\
$\mathrm{C}_{16: 2}$ & 15.31 & 279.28 \\
$\mathrm{C}_{18: 1}$ & 211.29 & \\
\hline Total & \multicolumn{2}{c}{}
\end{tabular}

It has been reported that melinjo peel contains several unsaponified compounds such as carotene (Siregar \& Margareta, 2019). Based on the unsaponified fatty acids composition, the result of this research shows that additive does not influence the quality of the soap. This is in line with the INS standard stating that the unsaponified fatty acid value generated from the hot process method should be below $0.5 \%$ because the compounds can be saponified better during the heating process. Thus, this process may result in high-quality soap bars.

\section{Antimicrobial Activity Test}

The antimicrobial activity test was performed according to Kirby-Bauer's disk diffusion method and the microbial growth inhibition as shown in Figure 2. The diameters of the melinjo soap inhibition zones with three different microbes, namely $S$. epidermidis, $S$. aureus, and $T$. mentagrophyte are shown in Figures 3,4 , and 5, respectively. Species of Staphylococcus are parts of the normal bacterial flora of human skin and mucosal surfaces. S. aureus is the most virulent pathogen, and $S$. epidermidis has been recognized as an innocuous commensal bacterium of human skin. This bacterium is categorized as an important human pathogen (Chessa et al., 2016). Trichophyton, Microsporum, and Epidermophyton are called dermatophytes or the genera of fungi that cause skin diseases in humans and animals (De Aguiar Peres,
Maranhão, Rossi, A \& Martinez-Rossi, 2010). These three species are chosen not only because of their pathogenicity but also because of their ability to represent groups of bacteria and fungi. Broadspectrum antimicrobial agents that are generally used in most approaches are to cover some of the possible pathogens commonly present in the body (Leekha, Terrell, \& Edson, 2011).

Based on NCCLS (Cavalieri et al., 2005), the data in this study are distributed into three criteria, i.e. susceptible $(\geq 21 \mathrm{~mm})$, moderate $(17-20 \mathrm{~mm})$, and resistant ( $\leq 16 \mathrm{~mm}$ ). The positive control (chloramphenicol $200 \mathrm{ppm}$ ) can inhibit microbe growth. The three microbes grow when they are in contact with the negative control (distilled water). The overall results show that there is an inhibited growth of $S$. aureus and $S$. epidermidis on every sample of the soap. However, the inhibition diameter is smaller than that in the positive control.

Figure 3 shows that Soap A (produced by cold process and water) performs the highest antibacterial activity against $S$. epidermidis while Soap B (hot process-water) shows the lowest activity. Statistical analysis shows that there is a difference in inhibition zone between the type and concentration of melinjo soap ( $p<0.05$ ). Based on Duncan's Multiple range test, it can be concluded that the best concentration is at $50 \mathrm{mg} / \mathrm{mL}$.

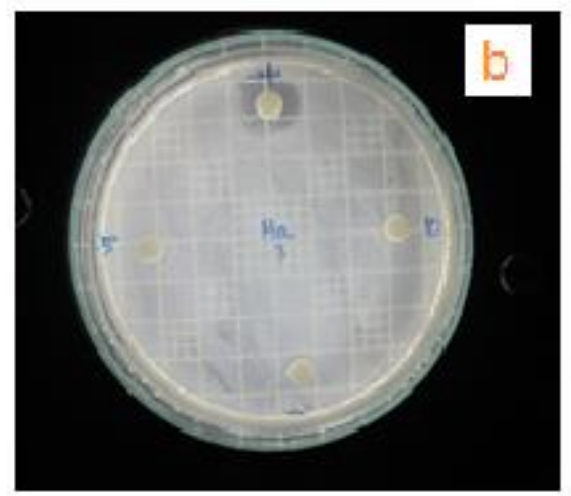

Figure 2. (a) Soap B, T. mentagrophyte on hour 48. (b) Soap B, S. aureus on hour 8. 


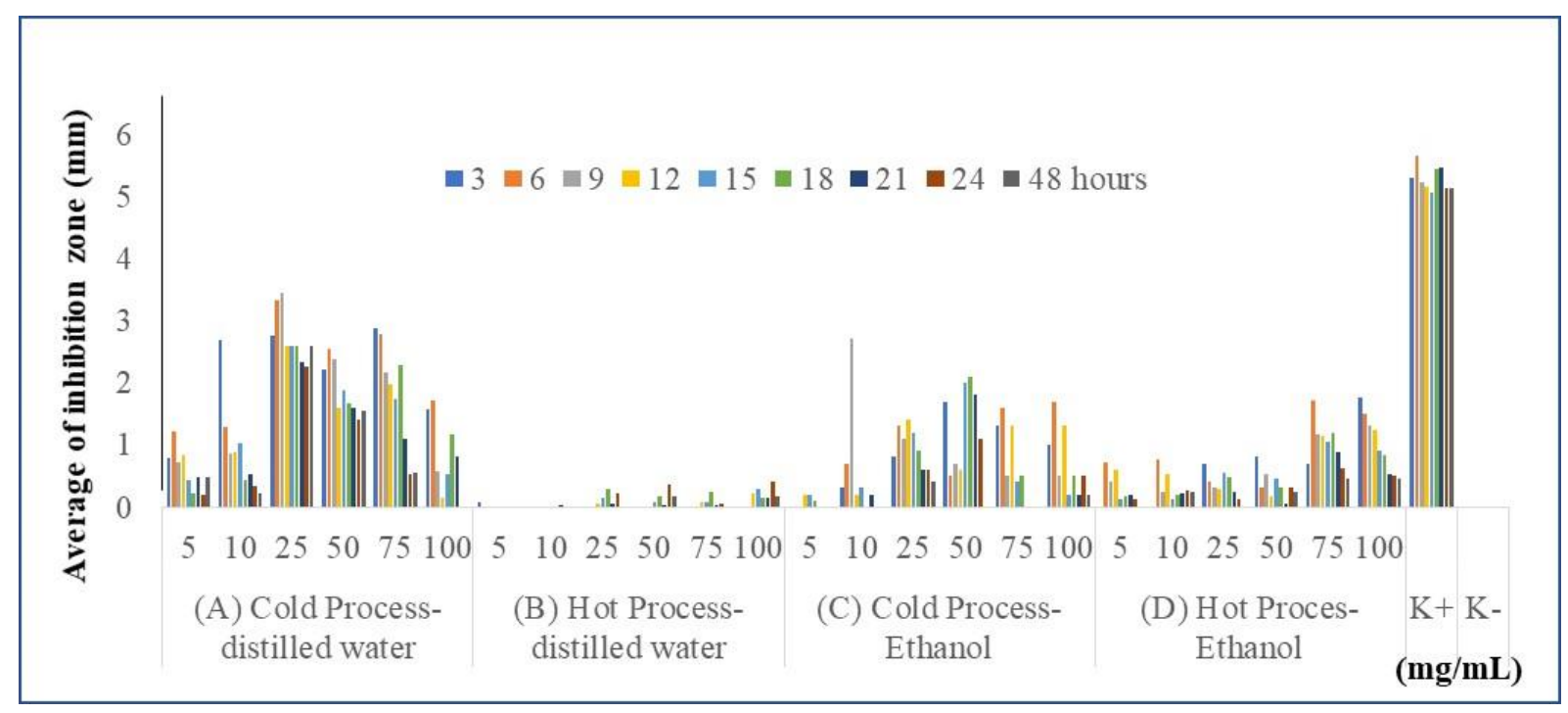

Figure 3. Diameter of inhibition zone of melinjo peel soap against $S$. epidermidis.

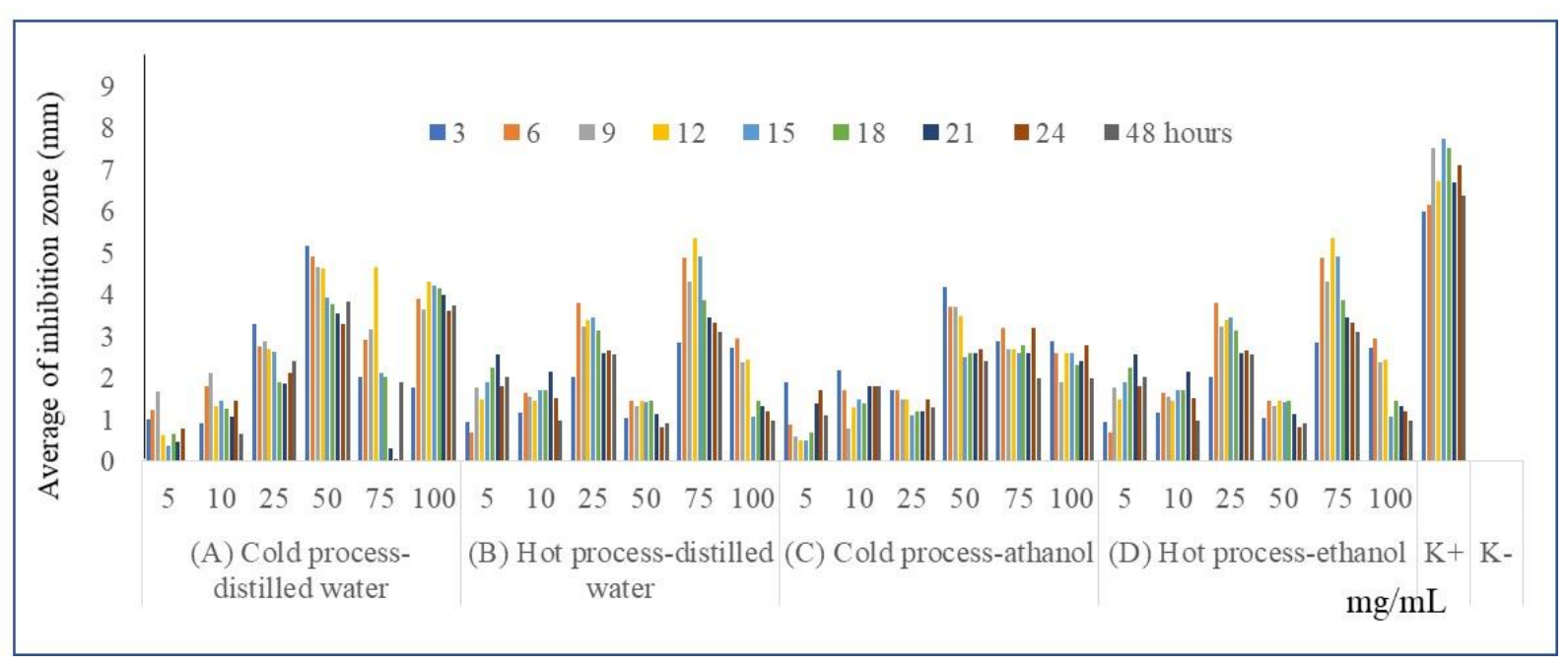

Figure 4. Diameter of inhibition zone of melinjo peel soap against $S$. aureus.

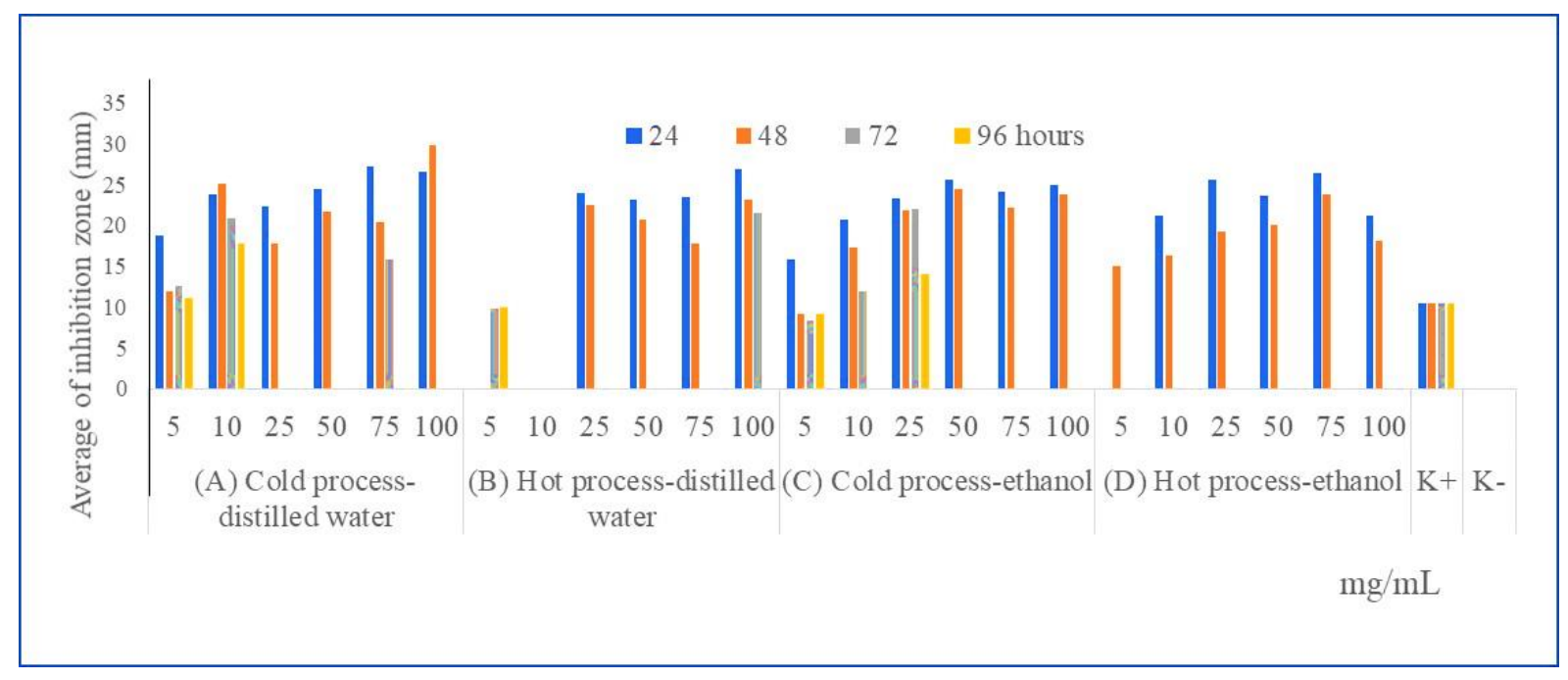

Figure 5. Diameter of inhibition zone of melinjo peel soap against $T$. mentagrophyte 
Figure 4 shows that every soap has growth inhibition activity against $S$. aureus. Analysis of the growth inhibition of $S$. aureus bacteria in melinio soap indicates some differences in the inhibition zone diameters in terms of melinjo soap types and concentrations ( $p<0.05)$. Based on Duncan's Multiple range test, it can be concluded that there is no significant difference between the 4 types of soaps. However, the best soap is Soap A as its concentration provides the best growth inhibition against $S$. aureus bacteria at $75 \mathrm{mg} / \mathrm{mL}$.

Figure 5 shows the melinjo soap antifungal test against $T$. mentagrophyte. The growth inhibition shown by $T$. mentagrophyte is bigger than that in the positive control. The fungal growth inhibition could still be observed until 96 hours of incubation and 3 categorizations, namely susceptible, medium, and resistant. Soap D does not show any growth inhibition on hours 72 and 96 . The longer incubation time shows a lesser inhibition zone while a higher concentration of melinjo soap shows an increase in the average inhibition zone diameter. Data analysis shows that there is no significant difference in all the soap types. Based on further tests performed using Duncan's Multiple range test, it can be concluded that there is no significant difference among the types of concentration. However, from the highest inhibition diameter zone against $\mathrm{T}$. mentagrophyte, the best soap type is $A(29.98 \mathrm{~nm})$ at $100 \mathrm{mg} / \mathrm{mL}$ concentration.

We use different durations to determine the inhibition zone because antibiotic treatment is timedependent (Greulich, Doležal, Scott, Evans, \& Allen, 2017). Based on (Ozer, Ozturk, Altunkan, Cinel, \& Oral, 2002) some conditions can affect the inhibitory, including dose, sample dilution, duration of contact with organisms, as well as numbers and types of microorganisms present in the culture. Antimicrobial activity can be analyzed and defined at both nonlethal bacteriostatic and lethal bactericidal levels. By measuring the zone of inhibition at different times, we can see whether the antimicrobial is bacteriostatic or bactericidal. It is shown in this study, that almost all treatments show a decrease in the diameter of the inhibition zone when its duration is longer. This indicates that the antimicrobial in this study is bacteriostatic.

It is evident that each soap presents different activities towards different bacteria. S. aureus and $S$. epidermidis are similar species and share the same potential virulence factors that can cause infection. These two species can form a biofilm. The formation of this biofilm has been recognized as a very important factor contributing to the virulence of these pathogenic bacteria. Biofilm is an agglomeration of cells attached to a surface that is usually embedded in a heterogeneous matrix. The formation of biofilms embedded in the exopolysaccharide matrix is one of the resistance mechanisms used by bacteria to survive in the presence of antibiotics (Cepas et al., 2019). According to (Chessa et al., 2016), S epidermidis can form thicker biofilm than S. aureus. In that study, it was found that there were differences in the distribution of different genes in several strains of these two species using Polymerase Chain Reaction (PCR). IcaA gene was found in $63 \%$ of $S$. epidermidis strains and $35 \%$ of S. aureus strains. Bap-like protein (Bab homologue protein) gene was found in $36 \%$ of the S. epidermidis strain but was absent in $S$. aureus strain, and potassium dependent ATPase (kdp) gene was found in $28 \%$ of $S$. epidermidis strains and was absent in $S$. aureus strains. The peptide precursor accessory gene regulator (AgrD) was more abundant in $S$. aureus $(86 \%)$ than $S$. epidermidis strains (46\%). The intercellular cluster adhesin (icaA) gene is involved in synthesis of poly $\mathrm{N}$-acetylglucosamine for intercellular adhesion, it plays a role in biofilm formation (Lee et al., 2018). Bhp protein (Bap homologue protein) is useful for helping initiate adhesion formation through hydrophobic interactions (Salgueiro, lorio, Ferreira, Chamon, \& Dos Santos, 2017). Agr is a virulenceassociated sensor regulator systems that induce the production of toxins, exoproteins, and the regulation of biofilm formation. KdpD-KdpE is involved in virulence in some bacteria (Xue, You, Hong, Sun, \& Sun, 2011).

In this study, the soap with melinjo peel additive performs higher inhibition against the growth of $T$. mentagrophyte than $S$. epidermidis and $S$. aureus. Each antimicrobial has different mechanisms of action, both against bacteria and fungi as fungi and bacteria have different structures. A compound has different mechanisms as an antifungal or an antibacterial (Ghannoum \& Rice, 1999). In this study, antimycotic activity of the soap is higher than the antibacterial activity. This is probably due to the activity of the soap-active compounds being more of antifungal activity. In addition, it is also due to the ability of bacteria to form biofilms thus making them more resistant to the given antimicrobial.

\section{The Effect Of Solvent and Soap Making Method on} Antimicrobial Activity

It has been reported that the compounds in melinjo are usually produced by polar compounds such as anthocyanin (Tarmizi, Lalasari, \& Saragih, 2015), resveratrol, flavonoid, and polyphenol (Aye Thein, Htay Shwe, \& Yi Myint, 2019). The extraction of anthocyanin contained in red melinjo peels are mostly performed using ethanol (Tarmizi et al., 2015), bioethanol (Husnil et al., 2019), and ethyl acetate (Parhusip, Anugrahati, Sinaga, Honga, \& Angel, 2019). The ethanol extract of melinjo peel has also been reported to be used as a natural dye (Hardani \& Angraini, 2019). During the experiment, the extraction of melinjo peel using polar solvents such as water and ethanol was conducted. It was found that soap produced from water extracted melinjo had higher microbial growth inhibition activity than that extracted 
using ethanol. The solid ethanol extract was obtained from evaporation. We used $100 \mathrm{~mL}$ of water extract from the heating extraction directly to dissolve sodium hydroxide as a reagent in the saponification reaction. Thus, the water extract was distributed better in the soap than the ethanol extract in solid form. The water extract presented better anti-microbial activity than ethanol. Soap A produced through the cold process and melinjo water extract additive had the best antimicrobial activity with the highest diameter inhibition zone (Figure 3, 4, 5). This finding is supported by the reported work mentioning that the aqueous extract of walnut green husk is effective in inhibiting microbial growth (Fernández-Agulló et al., 2013). However, this finding contradicts some other reported studies showing that the antimicrobial activity of ethanol extract is better than that of water extract (Sen \& Batra, 2012; Soehendro, Manuhara, \& Nurhartadi, 2015).

It is also reported that the higher extraction temperature increased the phenol total and microbial activity. The minimum inhibitory concentration (MIC) of the ethanol extract, $50 \%$ ethanol, and water of $B$. retusa bark decrease the inhibition of $S$. aureus growth (Tatiya, Tapadiya, Kotecha, \& Surana, 2011). In this study, the melinjo peel extraction using water was done by heating, whereas extraction using ethanol was performed through maceration at room temperature. Temperature influences the extraction process efficiency (Dorta, Lobo, \& Gonzalez, 2012). The higher the extraction temperature, the more extracted polyphenol content which leads to the increases in biological activity. The soap produced using water extracted melinjo peels shows higher antimicrobial activity because of the heating effect in the melinjo peel extraction process. Based on the quality test and the soap activity test data using four treatments, it is found that these soaps met the INS standard except for the unsaponified fatty acid only. Based on the inhibition zone diameter number, the melinjo peel soap is more active as an antifungal than an antibacterial. Furthermore, it can be concluded that Soap A synthesized using the cold process method and distilled water as solvent shows the best antimicrobial activity.

\section{CONCLUSIONS}

The quality of all soaps produced using melinjo peel additive meets the INS standards except for the unsaponified fatty acid in cold process saponification. Therefore, based on this finding it is suggested to use triglycerides with balanced fatty acid composition to get a better soap quality. The soap produced using melinjo water extract has higher antimicrobial activity than that produced using ethanol extract. The soap with melinjo peel additive shows higher inhibition against the growth of $T$. mentagrophyte than $S$. epidermidis and $S$. aureus. The result of this research shows that soaps with melinjo peel additive are potential to be used as antimicrobial soap.

\section{ACKNOWLEDGMENTS}

Our gratitude goes to the Dean of the Faculty of Mathematics and Natural Sciences and the Head of Institute of Research and Community Service of Universitas Negeri Yogyakarta for the research grant funding in 2019. We also want to express our gratitude to the staff of the Microbiology Laboratory of the Faculty of Mathematics and Natural Sciences for the help provided during research.

\section{REFERENCES}

Abhishek, S., Ruchi, J., Payal, S., \& Nilesh, J. (2019). Skin whitening efficacy of Gnetum gnemon L. seed extract. Journal of Drug Delivery and Therapeutics, 9(2), 227-230.

Amsal. (2020). The Water, soap, sanitation, and handwashing facilities are Associated with COVID-19 transmission in 44 Countries. Jurnal Ilmu Kesehatan, 14(1), 50-57.

Asmira, S. (2015). Semi-automated machine to make soap from used. Universiti Teknikal Malaysia Melaka.

Aye Thein, A., Htay Shwe, H., \& Yi Myint, Y. (2019). Structure identification of stilbenoid compound isolated from the stem of Gnetum gnemon L. Using Spectroscopic Methods. IEEE SEM, 7(8), 66-70.

Beiu, C., Mihai, M., Popa, L., Cima, L., \& Popescu, M. N. (2020). Frequent hand washing for COVID19 prevention can cause hand dermatitis: Management Tips. Cureus, 12(4), 1-7. https://doi.org/10.7759/cureus.7506

BSN. (2016). Sabun mandi padat, SNI 3532:2016.

Burleson, G., Butcher, B., Goodwin, B., Sharp, K., \& Ruder, B. (2017). Soap-making process improvement: Including social, cultural and resource constraints in the engineering design process. International Journal for Service Learning in Engineering, Humanitarian Engineering and Social Entrepreneurship, 12(2), 81-102. https://doi.org/10.24908/ijsle.v12i2.7572

Cavalieri, S. J., Rankin, I. D., Harbeck, R. J., Sautter, R. L., McCarter, Y. S., Sharp, S. E., Ortez, J. H., \& Carol A. Spiegel. (2005). Manual of Antimicrobial susceptibility testing. In Marie B Coyle (Ed.), American Society for Microbiology (3rd ed., pp. 101-117).

Cepas, V., López, Y., Muñoz, E., Rolo, D., Ardanuy, C., Martí, S., Xercavins, M., Horcajada, J. P., Bosch, J., \& Soto, S. M. (2019). Relationship between biofilm formation and antimicrobial resistance in Gram-negative bacteria. Microbial Drug Resistance, 25(1), 72-79. https://doi.org/10.1089/mdr.2018.0027 
Chessa, D., Ganau, G., Spiga, L., Bulla, A., Mazzarello, V., Campus, G. V., \& Rubino, S. (2016). Staphylococcus aureus and staphylococcus epidermidis virulence strains as causative agents of persistent infections in breast implants. PLOS ONE, 11(1), 1-15. https://doi.org/10.1371/journal.pone.0146668

De Aguiar Peres, N. T., Maranhão, F. C. A., Rossi, A., \& Martinez-Rossi, N. M. (2010). Dermatophytes: Host-pathogen interaction and antifungal resistance. Anais Brasileiros de Dermatologia, 85(5), 657-667. https://doi.org/10.1590/s036505962010000500009

Dorta, E., Lobo, M. G., \& Gonzalez, M. (2012). Reutilization of mango byproducts: Study of the effect of extraction solvent and temperature on their antioxidant properties. Journal of Food Science, 77(1), 80-88. https://doi.org/10.1111/i.1750$3841.2011 .02477 . x$

Faiola, A. M. (2013). Soap crafting. Storey Publishing. Fernández-Agulló, A., Pereira, E., Freire, M. S., Valentão, P., Andrade, P. B., González-álvarez, J., \& Pereira, J. A. (2013). Influence of solvent on the antioxidant and antimicrobial properties of walnut (Juglans regia L.) green husk extracts. Industrial Crops and Products, 42(1), 126-132. https://doi.org/10.1016/i.indcrop.2012.05.021

Flavell, T. (2016). Using soap substitutes, bath additives, and leave-on emollients. Journal of Community Nursing, 30(3), 29-34.

Ghannoum, M. A., \& Rice, L. B. (1999). Antifungal agents: Mode of action, mechanisms of resistance, and correlation of these mechanisms with bacterial resistance. Clinical Microbiology Reviews, 12(4), 501-517. https://doi.org/10.1128/cmr.12.4.501

Giuliano, C. A., \& Rybak, M. J. (2015). Efficacy of triclosan as an antimicrobial hand soap and its potential impact on antimicrobial resistance: $A$ focused review. Pharmacotherapy, 35(3), 328336. https://doi.org/10.1002/phar.1553

Greulich, P., Doležal, J., Scott, M., Evans, M. R., \& Allen, R. J. (2017). Predicting the dynamics of bacterial growth inhibition by ribosometargeting antibiotics. Physical Biology, 14(6). https://doi.org/10.1088/1478-3975/aa8001

Hall, N., Hill, M., Moaddel, T., \& Al, E. (2016). Soap manufacturing technology (Luis Spitz (ed.); second edi).

Handayani, S., Kristianingrum, S., \& Rakhmawati, A. (2018). Standard quality and antibacterial activity tests of clove oil in solid soap production against Staphylococcus aureus, Staphylococcus epidermidis and Escherichia coli. Oriental Journal of Chemistry, 34(5). 2410- 2417. https://doi.org/10.13005/ojc/340524

Handayani, S., Kristianingrum, S., Rakhmawati, A., \&
Khairuddean, M. (2020). Formulation and antifungal activities of Syzygium aromaticum essential oil contained in natural bath soap. International Journal of Research in Pharmaceutical Sciences, 11(SPL4), 16631669.

https://doi.org/10.26452/iirps.v1 1 ispl4.4354

Hardani, \& Angraini, L. M. (2019). Enhanced performance of dye-sensitized solar cells using melinjo peel (Gnetum Gnemon) dye as sensitizer. Indonesian Physical Review, 2(3), 106-115.

Husnil, Y. A., Tarmizi, E., Edyatika, A. Z., Nusandari, M. A., Lalasari, L. H., \& Saragih, R. (2019). Economic feasibility study of food-grade dye production from red melinjo peels. Rasayan J. Chem., 12(2), 641-649.

Kato, E., Tokunaga, Y., \& Sakan, F. (2009). Stilbenoids isolated from the seeds of melinjo (Gnetum gnemon L .) and their biological activity. Journal of Agricultural and Food Chemistry, 57, 2544-2549.

Lee, S., Kim, S., Lee, H., Ha, J., Lee, J., Choi, Y., Oh, H., Yoon, Y., \& Choi, K. H. (2018). icaA Gene of staphylococcus aureus responds to $\mathrm{NaCl}$, leading to increased biofilm formation. Journal of Food Protection, 81(3), 412-416. https://doi.org/10.4315/0362-028X.JFP-17238

Leekha, S., Terrell, C. L., \& Edson, R. S. (2011). General principles of antimicrobial therapy. Mayo Clinic Proceedings, 86(2), 156-167. https://doi.org/10.4065/mcp.2010.0639

McMurry, J. (2016). Organic chemistry (9th ed.). Cengage Learning.

Ozer, Z., Ozturk, C., Altunkan, A. A., Cinel, I., \& Oral, U. (2002). Inhibition of bacterial growth by lignocaine in propofol emulsion. Anaesthesia and Intensive Care, 30(2), 179-182. https://doi.org/10.1177/0310057×02030002 09

Parhusip, A.J.N., Anugrahati, N.A., Sinaga, W.S.L., Honga, J., Angel, V. (2019). Stabilization of red melinjo peel (Gnetum Gnemon L) ethyl acetate extract as antibacterial agent. Journal of Functional Food and Nutracetical, 1(1), 2-12.

Perencevich, E. N., Wong, M. T., \& Harris, A. D. (2001). National and regional assessment of the antibacterial soap market: A step toward determining the impact of prevalent antibacterial soaps. American Journal of Infection Control, 29(5), 281-283. https://doi.org/10.1067/mic.2001.115469

Salgueiro, V. C., lorio, N. L. P., Ferreira, M. C., Chamon, R. C., \& Dos Santos, K. R. N. (2017). Methicillin resistance and virulence genes in invasive and nasal Staphylococcus epidermidis isolates from neonates. BMC Microbiology, 17(1), 1-10. https://doi.org/10.1186/s12866- 


$$
\text { 017-0930-9 }
$$

Semilin, V. (2014). Production of soap from Sesamum indicum (Sesame seed) (Issue January). Universiti Malaysia Pahang.

Sen, A., \& Batra, A. (2012). Sen, A., \& Batra, A. (2012). Evaluation of antimicrobial activity of different solvent extracts of medicinal plant: Melia azedarach L. Int J Curr Pharm Res, 4(2), 67-73.

Setiati, S., \& Azwar, M. K (2020). COVID-19 and Indonesia. Acta Medica Indonesiana, 52(1), 84-89.

https://www.researchgate.net/publication/340 645813

Sharma, L., Agarwa, G., \& Kumar, A. (2003). Medicinal plants for skin and hair care. 2(January), 62-68.

Siregar, T. M., \& Margareta, M. (2019). Microencapsulation of carotenoids from red melinjo (Gnetum gnemon L.) peels extract. Journal of Physics: Conference Series, 1351(1). https://doi.org/10.1088/17426596/1351/1/012031

Soehendro, A. W., Manuhara, G. J., Nurhartadi, E., (2015). Effects of temperatures on antioxidant and antimicrobia activity of melinjo seed (Gnetum gnemon L.) with ethanol and water as solvent. Jurnal Teknosains Pangan, IV(4), 1524.

Tarmizi, E., Lalasari, L. H., \& Saragih, R. (2015). The effect of solvents on the stabilities (color and $\mathrm{Fe}$ ) of anthocyanin isolated from the red-colormelinjo peels. In AIP Conference Proceedings. 1699(1); 060018). AlP Publishing LLC.2. https://doi.org/10.1063/1.493837

Tatefuji, T., Yanagihara, M., Fukushima, S., \& Hashimoto, K. (2014). Safety assessment of melinjo (Gnetum gnemon L.) seed extract: Acute and subchronic toxicity studies. Food and
Chemical Toxicology, 67, 230-235. https://doi.org/10.1016/j.fct.2014.02.030

Tatiya, A. U., Tapadiya, G. G., Kotecha, S., \& Surana, S. J. (2011). Effect of solvents on total phenolics, antioxidant and antimicrobial properties of Bridelia retusa Spreng. stem bark. Indian Journal of Natural Products and Resources, 2(4), 442-447.

Vidal, N. P., Adigun, O. A., Pham, T. H., Mumtaz, A., Manful, C., Callahan, G., Stewart, P., Keough, D., \& Thomas, R. H. (2018). The Effects of cold saponification on the unsaponified fatty acid composition and sensory. Molecules, 23(2356), $1-20$.

https://doi.org/10.3390/molecules23092356

Wada, O. Z., \& Oloruntoba, E. O. (2021). Safe Reopening of schools during COVID-19: An Evaluation of handwash facilities and students' hand hygiene knowledge and practices. European Journal of Environment and Public Health, 5(2), em0072. https://doi.org/10.21601/ejeph/9704

Wazir, D., Ahmad, S., \& Muse, R. (2011). Antioxidant activities of different parts of Gnetum gnemon $L$ .20(2), 234-240. https://doi.org/10.1007/ s13562-011-0051-8

Wong, D. W. S., \& Li, Y. (2020). Spreading of COVID19: Density matters. PLoS ONE, $15(12$ December). https://doi.org/10.1371/JOURNAL.PONE.024 2398

Xue, T., You, Y., Hong, D., Sun, H., \& Sun, B. (2011). The Staphylococcus aureus KdpDE twocomponent system couples extracellular $\mathrm{K}^{+}$ sensing and agr signaling to infection programming. Infection and Immunity, 79(6), 2154-2167.

https://doi.org/10.1128/IAl.01180-10 